\title{
TRADISI REBO WEKASAN DI DESA SUCI KECAMATAN MANYAR KABUPATEN GRESIK (KAJIAN FUNGSI SOSIAL DAN NILAI BUDAYA)
}

\author{
Siti Mahmudah Yanti \\ Institut Pesantren Sunan Drajat Paciran Lamongan \\ Telp/Hp.085648078090 / 081218274551 \\ Mahmudahyanti@gmail.com
}

\begin{abstract}
Abstrak: Tujuan penelitian ini adalah untuk mengetahui tradisi Rebo Wekasan dan men eladani tradisi Rebo Wekasan yang terun temurun dilakukan oleh masyarakat Desa Suci Kecamatan Manyar Kabupaten Gresik.Penelitian ini menggunakan pendekatan kualitatif deskriptif yang dikemukakan oleh Sugiyono dengan analisis deskriptif dan isi.Hasil penelitian ini diharapkan dapat memberikan kontribusi pemikiran dan gagasan ilmiah mengenai kebiasaan masyarakat jawa dalam melestarikan budaya nenek moyang dalam hal ini Tradisi Rebo Wekasansebagai cagar budaya di daerah tersebut. Simpulan penelitian ini adalah (1) mempertebal keimanan dan ketakwaan terhadap Allah SWT karena pada dasarnya Tradisi Rebo Wekasan yang diperingati pada bulan shafar adalah untuk meminta perlindungan kepada Allah SWT karena pada bulan tersebut banyak musibah dan malapetaka, (2) terwujudnya kebersamaan dan kerukunan antar lapisan masyarakat yang antusias dalam memperingati Tradisi Rebo Wekasan dengan saling gotong-royong dan bahu-membahu dalam melaksanakan kegiatan tersebut.
\end{abstract}

Kata-kata kunci: tradisi rebo wekasan, struktur naratif, fungsi, dan nilai budaya

\begin{abstract}
The purpose of this study was to find out the tradition of Rebo Wekasan and follow the tradition of Rebo Wekasan which was carried out by the Suci Kecamatan Village Manyar District, Gresik. This study used a descriptive qualitative approach proposed by Sugiyono with descriptive analysis and content. The results of this study are expected can contribute scientific thoughts and ideas about the habits of the Javanese people in preserving ancestral culture in this case the Rebo Wekasan Tradition as a cultural preserve in the area. The conclusions of this study are (1) strengthening the faith and piety of Allah SWT because basically the Tradition of Rebo Wekasan which is commemorated in the month of prayer is to ask for protection from Allah SWT because in that month there are many calamities and disasters, (2) the realization of togetherness and harmony between layers an enthusiastic community in commemorating the Rebo Wekasan Tradition by mutual cooperation and shoulder to shoulder in carrying out these activities.
\end{abstract}

Keywords: tradition rebo wekasan, struktural study, function, and cultural value 


\section{PENDAHULUAN}

Masyarakat Indonesia mempunyai keanekaragaman yang dilatar belakangi oleh keadaan budaya Agama, dan kepercayaan yang berbeda-beda. Hal itu merupakan kebudayaan nasional yang tidak ternilai dan patut dibanggakan. Salah satu contoh kebudayaan nasional bangsa Indonesia adalah sastra lisan. Sastra lisan adalah kesusastraan yang mencakup ekspresi kesusastraan warga suatu budaya yang disebarkan dan di turun temurunkan secara lisan atau dari mulut kemulut (Hutomo, 1991:1). Penyebarannya melalui mulut, maksudnya budaya yang disebarkan baik dari segi waktu maupun ruang dilakukan melalui mulut.

Kehidupan sastra lisan selalu mengalami perubahan sesuai dengan dinamika masyarakat pendukungnya. Ada beberapa sastra lisan di Indonesia yang telah hilang sebelum dapat didokumentasi. Sementara sebagian sastra lain yangmasih bertahan, berada diambang kepunahan karena berbagai kendala yang dihadapinya. Oleh karena itulah, suatu usaha pelestarian sastra lisan perlu dilakukan. Apabila sastra lisan dibiarkan terus menerus tanpa ada usaha penelitian, sementara proses perubahan dan kepunahan sastra lisan terus berlangsung, maka bersamaan dengan itu kekayaan budaya yang terkandung didalam sastra lisan akan punah pula.

Sastra lisan ini dapat dikaitkan dengan studi faktor, karena sastra lisan merupakan bagian dari Ilmu folklor. Brundvand (dalam Danandjaja, 2002:2) mendefinisikan folklor merupakan sebagian kebudayaan suatu kolektif yang tersebar dan diwariskan secara turuntemurun diantara kolektif macam apa saja, secara trandisional dalam versi yang berbeda baik dalam bentuk lisan maupun contoh yang disertai dengan alat guna pembantu pengingat.
Sastra lisan adalah salah satu bagian budaya yang dipelihara oleh masyarakat pendukungnya secara turuntemurun dan ditukarkan langsung kepada orang lain. Sastra merupakan pencerminan situasi, kondisi, dan adat istiadat suatu masyarakat. Pertumbuhan dan perkembangan sastra suatu masyarakat merupakan gambaran pertumbuhan dan perkembangan budaya, khususnya bahasa masyarakat tersebut. Sastra merupakan budaya yang menjadikan bangsa sebagai medianya dan erat kaitannya dengan kemajuan bahasa masyarakat pendukungnya. Masyarakat tradisional yang sifat kebersamaannya lebih besar dari pada sifat perseorangannya menyebabkan sastra lisan lebih akrab dari pada sastra tulis (Depdikbud, 1998:1).

Sastra lisan merupakan barisan budaya daerah turun-temurun yang dapat dikembangkan juga dimanfaatkan serta mempunyai nilai-nilai luhur yang cukup tinggi dalam hubungan usaha perbinaan dan penentuan sastra. Anggapan sastra dapat berfungsi sebagai suatu perkembangan bahasa daerah dan juga pengungkapan dan pikiran dan nilai-nilai kebudayaan (Nebarth, 1985:1). Hal ini jelas bahwa sastra lisan mempunyai kedudukan dan fungsi yang penting sehingga sastra lisan perlu di selamatkan, dipelihara dan dikembangkan. Usaha menyelamatkan semacam ini bukan saja penting dan berguna bagi masyarakat pendukung sastra lisan yang bersangkutan, melainkan juga bermanfaat bagi kepentingan nasional. Hal ini relevan dengan kebijakan pemerintah dalam bidang kebudayaan yang antara lain bertujuan meningkatkan pembinaan dan pemeliharaan kebudayaan nasional.

Sastra lisan yang diturunkan secara turun-temurun ini dapat pula dipelajari untuk memperoleh gambaran mengenai kebudayaan yang berkembang pada waktu mereka hidup pengetahuan yang 
diperoleh dari sastra lisan ini dapat membantu dalam usaha mempelajari, mengetahui, mengerti dan kemudian menyajikan sejarah perkembangan bangsa Indonesia. Disamping itu sastra lisan juga berperan sebagai wahana pemahaman gagasan dan pewarisan tata nilai yang tumbuh di masyarakat.

Pulau Jawa termasuk daerah yang memiliki dan mempunyai banyak kekayaan budaya salah satu diantaranya adalah sastra lisan, sastra lisan mempunyai kedudukan dan fungsi yang penting sehingga sastra lisan perlu diselamatkan, dipelihara, dan di kembangkan untuk meningkatkan pembinaan dan pelihara nasional. Pentingnya usaha melestarikan sastra lisan dipulau jawa ini karena sastra lisan hanya tersimpan dalam ingatan para orang tua (sesepuh) yang jumlahnya kian hari kian berkurang. Padahal, sastra lisan dapat berfungsi sebagai identitas kebanggaan suatu daerah.

Salah satu sastra lisan dalam kajian ini adalah Tradisi Rebo Wekasan di Desa Suci Kecamatan Manyar Kabupaten Gresik (Kajian Struktur Naratif, Fungsi,dan Nilai Budaya) Pada dasarnya Tradisi Rebo Wekasan memang sudah identik dan melekat dengan Budaya Jawa dimana sejak nenek moyang dulu dimasa kejayaan Sunan Giri. Pada dasarnya istilah Rebo Wekasan bila ditinjau dari Bahasa Arab adalah Arba'a yang berarti rabu dan Hasanun yang berarti bagus.Artinya hari rabu sebaiknya dipergunakan untuk melakukan hal-hal yang bagus.Sedangkan di tinjau dari bahasa jawa berarti Rebu Pungkasan atau Rebu yang terakhir pada setiap bulan Shafar. Berkaitan dengan itu para ulama menyebutkan bahwa pada Bulan Shafar Allah SWT menurunkan 320.000 sampai 500.000 lebih macam penyakit atau musibah.Untuk mengatisipasinya agar terhindar dari musibah tersebut para ulama melakukan Tirakatan itu beribadah menghadap Allah SWT seraya berdoa agar terhindar dari malapetaka tepat di hari rabu terakhir di bulan Shafar.Tradisi Rebo Wekasan yang ada di Desa Suci Kecamatan Manyar

Kabupaten Gresik juga ada hubungannya dengan nama Desa Suci, Tradisi Rebo Wekasan selain identik dengan keramaian juga memiliki nuansa Religius yang sedikit terlupakan oleh mayarakat, karena mereka mungkin tidak mengetahui persis apa yang melatar Belakangi munculnya Tradisi ReboWekasan di Desa Suci.

Nama Suci inilah yang mengilhami adanya Tradisi Rebo Wekasan. Tradisi ini konon terjadi sejak ditemukannya sumber air oleh seorang kerabat Kanjeng Sunan Giri pada tahun 1483 Masehi. Awalnya kerabat atau santri Kanjeng Sunan Giri tersebut diperintahkan untuk menyebarkan agama Islam ke sebelah barat Kota Gresik, semula kerabat tersebut tiba di sebuah tempat diujung selatan Desa Suci yaitu bertempat di Kampung Polaman kemudian disana didirikanlah Masjid yang berfungsi juga sebagai Pesantren Sebagai tempat untuk menuntut ilmu keagamaan. Kemudian untuk kebutuhan air dibuatkan subuah sumur yang dapat digunakan untuk bersuci dan dapat pula bermanfaat bagi masyarakat sekitar, karena saking besarnya manfaat air sumur itu kemudian dikenal dengan nama Sumur Gede yang dalam bahasa Indonesia berarti sumur besar.Kalau kita melihat sumur tersebut terlihat biasa-biasa saja ukurannya pun biasa akan tetapi manfaat sumur pada masa itu sangatlah besar sehingga masyarakat menyebutnya Sumur Gede.

Kebutuhan air lama-lama tidak mencukupi, maka atas petunjuk Kanjeng Sunan Giri diperintahkannya kerabat untuk menelusuri lereng bukit di sebelah utara kampung Polaman. Kerabat tersebut melihat rerimbunan pohon-pohon besar ditempat itu, lalu sang kerabat tersebut 
mendekat dan melihat-lihat dibawah rerimbunan pohon-pohon tersebut terdapat sumber air yang sangat jernih sekali dan sumbernya sangat besar sampai airnya meluap kepermukaan tanah sehingga bisa digunakan untuk kebutuhan Sesuci dan memenuhi syarat menurut Agama.Sehingga kampung tersebut dinamakan kampung suci atau Desa Suci.

Fungsi sosial adanya kegunaan suatu hal (KBBI) namun yang di maksud disini adalah fungsi sosial cerita. Fungsi sosial cerita adalah manfaat yang dapat di ambil oleh masyarakat secara luas. Oleh sebab itu fungsi-fungsi sosial Tradisi Rebo Wekasan Di Desa Suci Kecamatan Manyar Kabupaten Gresik ajianStruktur Naratif, Fungsi, Nilai Budaya) sampai saat ini setiap bulan Shafar masyarakat disekitar melakukan Khotmil Qu'ran, Istighotsah, Hadroh membaca sholawat Nabi dan diakhiri dengan kirap tumpeng Raksasa bersama masyarakat disekitarnya.

Berdasarkan uraian di atas, peneliti tertarik untuk meneliti dan menganalisis Tradisi ReboWekasan di Desa Suci Kecamatan Manyar Kabupaten Gresik (Kajian Struktur Naratif, Fungsi, dan Nilai Budaya). Peneliti juga berharap hasil penelitian tersebut dapat meningkatkan pemahaman terhadap sejarah, apresiasi dan hubungan masyarakat dengan lingkungannya. Jadi, penelitian sangat diperlukan untuk mengetahui fenomena masyarakat suatu daerah baik pada masa lampau maupun masa sekarang.

\section{METODE PENELITIAN}

Pendekatan dalam penelitian ini adalah pendekatan kualitatif bersifat diskriptif. Data yang diperoleh dari penelitian ini adalah dengan cara mencari data-data yang valid dari informan secara langsung dan signifikan. Sumber utama dalam penelitian ini diperoleh dari hasil wawancara dengan informan dan gambar tradisi masyarakat Jawa dalam menyambut bulan Shafar. Salah satu informan kunci yang peneliti tentukan untuk memperoleh data-data yang berhubungan dengan Tradisi Rebo Wekasan di Desa Suci Kecamatan Manyar Kabupaten Gresik adalah Mohammad Miftach.

Teknik pengumpulan data penelitian ini adalah teknik pengamatan, perekaman cerita, pencatatan, dan wawancara.

Teknik analisis data yang digunakan dalam penelitian adalah teknik analisis deskriptif dan teknik analisis isi. Adapun langkah-langkahnya adalah (1) analisis struktur naratif: membaca seluruh cerita hasil transkripsi, menggaris bawahi kata-kata yang penting, menganalis bagian-bagian cerita, (2) analisis terhadap nilai budaya: membaca traskripsi cerita, mengenali keadaan atau tradisi masyarakat sekitar, menafsirkan, dan menyimpulkan struktur naratif, fungsi, dan nilai budaya yang ada dalam cerita.

\section{HASIL DAN PEMBAHASAN Fungsi Sosial}

Tradisi Rebo Wekasan salah satu kebudayaan yang masih dilestarikan oleh masyarakat Gresik khususnya di Desa Suci. Tradisi tersebut tidak hanya bercerita tentang penyebaran Agama Islam ditanah Jawa tetapi juga mengajarkan tentang bagaimana cara mendekatkan diri kepada sang pencipta, tolong menolong, bekerja sama dengan orang lain dan lain-lain. Mungkin sebagian orang masih tabuh dengan Tradisi Rebo Wekasan khususnya masyarakat awam yang belum pernah mendengar bahkan melihatnya.Untuk itu penulis harus berjuang sekeras mungkin agar cerita tersebut tidak dianggap tabuh lagi oleh masyarakat lainnya. Pada dasarnya Tradisi Rebo Wekasan 
mempunyai fungsi-fungsi sosial, yang bermanfaat bagi masyarakat.

Diantaranya fungsi sosial Tradisi Rebo Wekasan di Desa Suci Kecamatan Manyar Kabupaten Gresik, sampai saat ini tradisi tersebut tetap dilestarikan oleh pemerintah daerah di Desa Suci bahkan air yang ada disendang masih difungsikan sebagai air minum karena sumber air yang begitu besar dan sangat jernih.Sedangkan Masjid yang dulu dibangun oleh Syeh Jamaludin Malik masih digunakan sebagai tempat ibadah dan kegitan keagamaan oleh masyarakat disekitar. Serta tempat ziarah oleh pengunjung yang ingin mendoakan perjuangan Syeh Jamaludin Malik yang menegakkan ajaran Agama Islam di daerah tersebut.

Dalam menganalisis fungsi cerita yang ada dalam Tradisi Rebo Wekasan di Desa Suci Kecamatan Manyar Kabupaten Gresik, penulis menggunakan teori fungsi sosial cerita menurut Alan Dundes (dalam Sulikan,2001:162) secara umum sastra lisan mempunyai lima fungsi, yaitu (1) sebagai pendidikan anak muda, (2) untuk meningkatan solidaritas suatu kelompok, (3) memberi sangsi sosial agar orang berlaku baik, (4) sebagai sarana kritik sosial,dan (5) sebagai pelarian yang menyenangkan dari kenyataan.Sebagai bukti temuan penulis berikut ini penulis mencantumkan hasil temuan penulis terhadap fungsi-fungsi sosial cerita yang terdapat dalam Tradisi Rebo Wekasan di Desa Suci Kecamatan Manyar Kabupaten Gresik:

\section{Sebagi Alat Pendidikan}

Tradisi Rebo Wekasan pada dasarnya bukan hanya sekedar dongeng atau cerita belaka tetapi tradisi tersebut mengandung banyak pelajaran, nilai-nilai kebaikan, maupun beberapa fungsi sosial yang dapat diambil manfaatnya oleh masyarakat sekitar ataupun masyrakat secara umum. Salah satu fungsi sosial cerita dalam Tradisi Rebo Wekasan adalah nilai-nilai yang terdapat dalam cerita tersebut dapat digunakan sebagi alat pendidikan bagi kaum muda khususnya bagi pelajar.

Secara umum Tradisi Rebo Wekasan menghadirkan tema tentang agama Islam, Karena pada zaman Majapahit masyarakat masih menganut ajaran agama Budha sehingga Kanjeng Sunan Giri mengutus Kerabatnya dalam hal ini Syeh Jamaludin Malik untuk menyebarkan ajaran Agama Islam di Pulau Jawa tepatnya di Kabupaten Gresik Desa Suci. Dengan cara membut Masjid yang dipergunakan sebagai pesantren atau tempat menimbah ilmu agama dan tempat beribadah.

Berdasarkan analisis yang telah penulis lakukan, ada beberapa nilai pendidikan yang dapat diambil dari cerita Rebo Wekasan. Diantaranya sebagai berikut (1) memperdalam ajaran agama Islam, (2) Mendekatkan diri kepada sang pencipta dengan cara beribadah.Untuk lebih jelasnya gambaran tersebut dapat dilihat pada bagian-bagian cerita sebagai berikut:

Pada masa kerajaan Majapahit masyarakat jawa mayoritas masyarakat jawa masih memeluk Agama Budha, Kanjeng Sunan Giripun mengutus kerabatnya untuk pergi menyebarkan ajaran Agam Islam dikampung Polaman Syeh Jamaludin Malik lantas membuat masjid untukTempat beribadah dan juga pesantren.Namun kendalanya tidak adanya air. Kemudian Syeh Jamaluddin Malik membuat sumur untuk bersuci dan kebutuhan lainnya.(Wawancara, Bapak Mohammad Miftach, Sekertaris Desa Suci, 11 Mei 2017).

Dari hasil wawancara di atas, terlihat bahwa hakikat manusia hidup di dunia ini harus bisa menjalankan kewajiban kita kepada Allah SWT, beribadah,bemunajat kepada-Nya agar selalu dalam petunjuk dan perlindungannya serta mempedalam ajaran agama Islam. 


\section{Meningkatkan Solidaritas Antar Kelompok}

Fungsi untuk meningkatkan solidaritas antar kelompok dalam cerita lisan yang penulis kaji terlihat jelas dalam bagian cerita yang menjelaskan bahwasanya Tradisi Rebo Wekasan sangatlah menonjolkan kebersamaan. Di mana terlihat jelas dalam tradisi tersebut akan penulis jelaskan melalui gambaran cerita sebagai berikut:

Setiap datangnya bulan Shafar Masyarakat disekitar berbondong-bondong, berkumpul melakukan Khotmil Qur'an, Membaca Sholawat Nabi, Istighosah,Tahlil,dan Kirab Tumpeng bersama-sama.Tanpa disadari terlihat jelas dengan tradisi tersebut akan memupuk dan meningkatkan solidaritas antar suatu kelompok. (Wawancara, Bapak Mohammad Miftach, Sekertaris Desa Suci,11 Mei 2017).

Terlihat jelas hubungan

kekeluargaan, solidaritas antar masyrakat tanpa memandang status sosial mereka bahu membahu bergotong-royong dalam merayakan Rebo Wekasan dan memupuk ukhuwah islamiah, yang pada zaman sekarang perpecahan telah melanda Negara kita Indonesia.

\section{Sebagai Sangsi Sosial Agar Orang Berlaku Baik}

Adapun fungsi sosial lain, yang dapat ditemukan dalam Tradisi Rebo Wekasan adalah sebagai sangsi sosial agar orang berlaku baik. Dalam hal ini yang dimaksud sangsi sosial adalah hukuman atau akibat kurang baik yang disebabkan oleh perilakunya sendiri. Selain itu, sangsi sosial juga dapat diartikan sebagai hukuman yang diberikan oleh Allah SWT kepada seseorang yang berlaku buruk agar ia sadar atau tobat dan dapat menyadari kesalahanya. Fungsi sosial dalam cerita Rebo Wekasan terlihat jelas dalam bagian kutipan cerita sebagai berikut:

Tradisi Rebo Wekasan identik dengan hal yang dianggap wajib untuk dilakukan karena pada bulan shafar adalah bulan yang penuh dengan musibah dan malapetaka terjadi.Untuk itu semua manusia harus membentenggi diri dengan cara mendekatkan diri kepada Allah SWT agar terhindar dari musibah tersebut.Barang siapa yang tidak membentengi diri dengan ketakwaan dan keimanan akan terkena malapetaka pada dirinya.(Wawancara, Bapak Mohammad Miftach, Sekertaris Desa Suci, 11 Mei 2017).

Dari hasil wawancara di atas, tampak jelas bahwa fungsi sosial cerita sebagai sangsi sosial agar orang berbuat baik. Bulan Shafar bisa dikatakan bulan sial karena karena Allah telah menurunkan 320.000 lebih penyakit dalam hal ini berbagai musibah yang tidak diduga akan menimpah pada manusia,apabila manusia tidak mau membenteggi dirinya dengan mendekatkan diri kepada Allah SWT maka akan terkena musibah.

\section{Sebagai Kritik Sosial}

Bukan hanya fungsi sosial cerita yang berkaitan dengan fungsi sebagai pendidikan anak muda, sebagai alat meningkatkan solidaritas suatu kelompok, sebagai sangsi sosial agar orang berlaku baik, cerita lisan mengenai Tradisi Rebo Wekasan juga mempunyai fungsi sebagai kritik sosial.

Seperti halnya yang kita ketahui, kelahiran karya sastra (termasuk karya sastra) tidak dapat dilepaskan dari kondisi lamanya.Dalam kajian sosiologis, karya sastra dapat dipandang sebagai salah satu alat untuk melakukan kritik sosial. Hal ini dikarenakan karya sastra banyak membicarakan kehidupan manusia dengan segala kompleksitas masalah yang dihadapinya.

Adanya kritik sosial dalam karya sastra inilah yang juga peneliti melihat dalam cerita Tradisi Rebo Wekasan. Secara umum, cerita lisan tersebut memberikan kritik sosial terhadap siapapun hendaknya saling menghormati, toleransi terhadap agama lain. Gambaran tersebut terlihat pada bagian cerita sebagai berikut: 
Tentang kepercayaan seseorang dimana pada bulan Shafar beberapa kalangan masyarakat meyakini bahwasanya pada bulan tersebut akan banyak musibah dan malapetaka. Sehingga masyarakat tesebut berbondong-bondong melakkan rialatan atau tirakat untuk mendekatkan diri kepada sang pencipta dengan caranya masing-masing seperti mandi malam dengan sumber air yang berbeda, bersemedi ditempat yang sunyi dan gelap dan lain-lain ataupun dengan cara yang lain yang dianggap sekelompok orang meyakini menurut kepercayaanya. (Wawancara, Bapak Mohammad Miftach, Sekertaris Desa Suci, 11 Mei 2017).

Berdasarkan beberapa uraian diatas,dapat penulis simpulkan bahwa secara tidak langsung Tradisi Rebo Wekasan mengandung kritik sosial. Kritik sosial yang menurut peneliti menonjol dalam hal ini adalah kritik yang ditunjukan pada manusia, agar menghormati kepercayaan orang lain atau toleransi.Karena dengan adanya perbedaan akan menambah keindahan dalam hidup ini.Negara kita Indonesia memiliki berbagai suku dan budaya, oleh karenanya kita tidak boleh memandang dari satu sisi saja atau beranggapan buruk tentang Tradisi Rebo Wekasan karena tradisi ini sangatlah baik bagi Agama Islam yang mengutamakan pendekatan diri kepada sang pencipta.

\section{Sebagai Pelarian yang Menyenangkan dari Kenyataan}

Tradisi Rebo Wekasan apabila kita cerna secara seksama bukan hanya sebagai tempat untuk penyebaran Agama Islam tetapi juga bisa berfungsi sebagai tempat menenagkan diri. Hal ini terlihat dari cerita yang tergambar dalam kutipan cerita yang penulis sajikan sebagai berikut:

Di masa lampau dimana masyarakat di Desa Suci dan masyrakat lainnya berbondong-bondong mengambil air yang sangat jernih dan meluapluap dipermukaan tanah untuk sesuci dan untuk memenuhi kebutuhan yang lainnya.Airnya yang begitu jernih dan bisa diminum secara langsung oleh masyarakat disekitar. Apabila kita bandingkan pada saat ini hal tersebut sudah tidak dapat kita jumpai untuk melihat air sepeti yang diceritakan dalam cerita tersebut.(Wawancara, Bapak Mohammad Miftach, Sekertaris Desa Suci,11 Mei 2017).

Berdasarkan uraian diatas dapat disimpulkan bahwa dala Tradisi Rebo Wekasan terkandung fungsi sosial cerita sebagai pelarian yang menyenangkan dari kenyataan. Maksudnya dalam cerita tersebut pembaca dapat membayangkan hal yang tidak pernah kita temukan dalam kehidupan sehari-hari atau sebenarnya.

\section{Nilai Budaya}

Apabila di tinjau secara sosiologis, sebuah karya sastra termasuk karya sastra lisan yang tidak dapat dilepaskan dari nila-nilai sosial dimana karya sastra itu dilahirkan begitu juga dengan Tradisi Rebo Wekasan. Tradisi tersebut apabila dikaji secara seksama juga tidak lepas dari aspek sosial Tradisi masyarakat Gresik yang kental nuansa jawa. Bila ditinjau dari aspek sosial budaya yang tergambar didalamnya tidak hanya berupa aspek sosial masyarakat Gresik tetapi juga aspek sosial masyarakat Jawa secara umum.

Selain itu menurut Koentjaraningrat (1990:190 ) menyatakan bahwa dalam masysrakat terdapat nilai budaya tertentu, dimana nilai budaya satu dengan nilai budaya yang lain berkaitan membentuk suatu sistem,kumpulan mengenai budaya yang hidup dalam masyarakat merupakan pedoman dari konsep ideal dalam kebudayaan sebagai pendorong terhadap arah kehidupan warga masyarakat terhadap objek tertentu dalam hal ini lingkungan.Dengan demikian nilai budaya membentuk sikap seseorang terhadap objek seperti manusia, hewan atau benda yang dihadapinya. Selain itu, Koentjaraningrat (1990:190) juga berpendapat bahwa suatu sistem nilai budaya merupakan konsepsi-konsepsi yang hidup dalam alam pikiran sebagian besar warga masyarakat mengenai hal-hal 
yang mereka anggap amat bernilai dalam hidup, karena itu suatu sistem nilai budaya biasanya berfungsi sebagai pedoman tertinggi bagi kelakuan manusia.Sistem tata kelakuan lain yang tingkatnya lebih kongkrit seperti aturan khusus, hukum, dan norma-norma semuanya juga berpedoman kepada sistem nilai budaya.

Berdasarkan analisis yang penulis lakukan terhadap Tradisi Rebo Wekasan, penulis dapat menemukan beberapa nilai budaya yang muncul di masyarakat Gresik diantaranya sebagai berikut:

\section{Nilai Kekeluargaan}

Nilai kekeluargaan yang muncul di Desa Suci dapat dibuktikan dengan kerukunan antar masyarakat di sekitar Desa Suci yang setiap Bulan Shafar berbondong-bondong mengikuti Tradisi Rebo Wekasan dari seluruh lapisan masyarakat Gresik tanpa memandang bulu.Adapun kutipan cerita yang akan penulis gambarkan sebagai berikut:

Setiap bulan Shafar masyarakat Gresik kususnya di Desa Suci senantiasa melakukan Tradisi tersebut, berbaur menjadi satu bermunajat kepada Allah SWT. (Wawancara Bapak Mohammad Miftach, Sekertaris Desa Suci,11 Mei 2017).

Dari ulasan kutipan di atas makna yang tertuang dalam nilai kekeluargaan adalah kebersamaan untuk mempererat ukhuwah antar sesama agar selalu terjalin dengan indah.

\section{Nilai Sosial}

Masyarakat Desa Suci mempunyai sikap sosial yang sangat tinggi dalam kehidupan sehari-hari. Sikap sosial mereka dapat dilihat dari kutipaan cerita yang akan penulis gambarkan sebagai berikut:

Sikap gotong royong, sikap saling membantu, sikap saling toleransi yang tinggi.Selain itu, dalam kehidupan sosial mereka dijiwai oleh sikap keterbukaan. Mereka tidak menutup diri dalam hidup bertetangga dan bermasyarakat.Seperti halnya dalam Tradisi Rebo Wekasan adanya kegiatan kirap Tumpeng Raksasa,dimana tumpeng tersebut dikirab oleh seluruh masyarakat Suci dan diikuti oleh seluruh lapisan masyrakat Gresik.( Wawancara Bapak Mohammad Miftach, Sekrtaris Desa Suci, $11 \mathrm{Mei}$ 2017).

Jiwa sosial inilah yang tersirat dari kutipan diatas tidak akan bisa digantikan dengan apapun. Kebersamaan, gotongroyong, solidaritas yang memperkuat persatuan Negara Indonesia.Tanpa semua itu kita tidak akan bisa mengenal satu sama lain, tidak akan bisa berbagi dengan sesama. Dengan adanya Tradisi Rebo Wekasan masyarakat bisa berbaur menjadi satu dari semua kalangan tanpa memandang status sosial.

\section{Nilai Relegius}

Ini sangat kental di Desa Suci Kecamatan Manyar Kabupaten Gresik, karena disekelilingnya dihimpit beberapa pondok pesantren pemuka Agama atau Kyai dan para Alim ulama. Selain itu terdapat beberapa makam-makam Wali Allah diantaranya makam Kanjeng Sunan Giri, makam Syeh Maulana Malik Ibrahim dan masih banyak makam Wali Allah yang ada di sekitar Kabupaten Gresik. Tergambar dalam kutipan yang penulis kutip sebagai berikut:Tradisi Rebo Wekasan mempunyai Nilai Religi yang sangat tinggi, karena kebiasaan para masyarakat membiasakan melakukan Qotmil Qur'an, Istighotsah, membaca Sholawat Nabi, Sholat Malam dan lainlain sebgai wujud ketaatan kepada Allah SWT. (Wawancara Bapak Mohammad Miftach, Sekertaris Desa Suci, 11 Mei 2017).

Dari hasil wawancara di atas, jelas bahwa makna yang terkandung dalam Tradisi Rebo Wekasan dalam kontek nilai religi sangatlah jelas tergambar semua semata-mata hanya ingin mendekatkan diri kepada sang pencipta Allah SWT.untuk menambah keimanan, 
ketakwaan, agar selalu dalam limpahan Rahmad, Hidayah, dan Inayah-Nya.

\section{SIMPULAN}

Cerita lisan mengenai Tradisi Rebo Wekasan mempunyai lima fungsi sosial cerita yaitu, (a) sebagai pendidikan anak muda, (b) untuk meningkatkan solidaritas suatu kelompok, (c) memberi sangsi ssosial agar orang berlaku adil, (d) sebagai sarana kritik sosial, dan (e) sebagai pikiran yang menyenangkan dari kenyataan.

Sebagai pendidikan bagi anak muda, setidaknya ada beberapa nilai pendidikan yang dapat diambil dari Tradisi Rebo Wekasan, yaitu (a) memperdalam ajaran agama Islam, (b) selalu dalam koridor yang benar amarma'ruf nahi mungkar.

Sebagai alat untuk meningkatkan solidaritas antar suatu kelompok, Tradisi Rebo Wekasansecara tidak langsung menggambarkan mengenai pentingnya dalam menjaga solidaritas antar sesama. Solidaritas yang tampak dalam Tradisi Rebo Wekasan lebih disebabkan oleh faktor persaudaraan, tergambar dari masyarakat Desa Suci Kecamatan Manyar Kabupaten Gresik yang sangat antusias untuk memperingatinya dan merayakannya. Semua masyarakat berkumpul melakukan kegiatan acara keagamaan seperti Khotmil Qur'an, Istighotsah, Sholawat Nabi bersamasama. Dari situlah terlihat jelas solidaritas antar suatu kelompok terjalin erat antar sesama.

Fungsi sosial cerita sebagai sangsi sosial agar orang berbuat baik. Dalam Tradisi Rebo Wekasan tergambar dalam bagian cerita yang mengambarkan masyarakat Desa Suci Kecamatan Manyar Kabupaten Gresik. Bulan Shafar adalah bulan dimana Allah SWT menurukan 320.000 - 500.000 lebih penyakit atau musibah ke bumi. Seyogyanya manusia lebih lagi mendekatkan diri agar terhindar dari segala malapetaka dan hal-hal yang tidak diinginkan.

Sebagia kritik sosial, secara tidak langsung Tradisi Rebo Wekasan mengandung kritik sosial. Kritik sosial menurut penulis ditujukan kepada manusia sang pencipta sama.Yang membedakan hanyalah ketakwaanya.

Sebagai pelarian yang menyenangkan dari kenyataan, Tradisi Rebo Wekasanterkandung fungsi sosial cerita sebagai pelarian yang menyenangkan dari kenyataan. Fungsi tersebut terlihat dalam cerita yang menceritakan adanya sumber air yang begitu jernih hingga air tersebut meluapluap kepermukaan tanah. Hal tersebut saat ini tidak pernah dapat kita temui.

Nilai budaya yang paling menonjol dalam Tradisi Rebo Wekasan di Desa Suci Kecamatan Manyar Kabupaten Gresik adalah setiap bulan Shafar seluruh lapisan masyarakat berbondong-bondong memperingati dan merayakan Tradisi Rebo Wekasan dengan cara Khotmil Qur'an, Istighotsah, membaca Sholawat Nabi, Sholat Malam dan lain-lain.

\section{DAFTAR PUSTAKA}

Aminudin, 2000. Pengantar Apresiasi Karya Sastra, Bandung: Sinar Baru Algensindo.

Arikunto, Suharsimi. 2006. Prosedur Penelitian Suatu Pendekatan Praktik. Jakarta: PT. RIneka Cipta.

Abdullah, Taufik. 2014. Agama Jawa (Abangan, Santri, Priyayi, dalam Kebudayaan Jawa), Bogor: Komunitas Bambu.

Danandjaja, James. 2002. Folklor Indonesia: Ilmu Gosip, Dongeng, dan Lain-lain. Jakarta: Grafiti Pres.

Depdikbud. 1998. Sastra Lisan Kayaan. Jakarta: Pusat Pembinaan dan 
Pengembangan Bahasa Departemen Pendidikan dan Kebudayaan.

Endaraswara, Suwardi. 2003. Metodelogi Penelitian Sastra: Konsep, Teori dan Aplikasi. Yogyakarta: Media Presindo.

Endraswara, Suwardi. 2009. Metodologi Penelitian Folklor: Konsep, Teori dan Apilasi. Yogyakarta: Media Presindo.

Hutomo, Suripan Sadi. 1991. Mutiara yang terlupakan: Pengantar Studi Sastra Lisan. Surabaya: HISKI Komisariat Jatim.

Keraf, Gorys. 2006. Diksi dan Gaya bahasa, Jakarta: Gramedia Pustaka Utama.

Koentjaraningrat. 1990. Manusia dan Kebudayaan di Indonesia. Jakarta: Djabatan.

Manasikana. 2008. Teori Sastra Konteporasi: Bandar Baru Bangi: Pustaka Karya

Mahmudah Yanti, Siti. 2010. Legenda Brumbun di Dusun Tepanas,Desa Kranji, Kecamatan Paciran, Kabupaten Lamongan (Kajian Struktur Naratif, Fungsi, dan Nilai Budaya). Skripsi yang tidak dipublikasikan.
Musthofa, Bisri. 2008. Metode Penuisan Skripsi dan Tesis. Yogyakarta: Optimus.

Moleong, Lexy J. 2001. Metodelogi Peneitian Kualitatif. Bandung: PT. Remaja Rosda Karya.

Nebart,Paul. 1985. Sastra Sangir Taland. Jakarta: Pusat pembinaan dan Pengembangan Bahasa: Depdikbud.

Nurrozuqi. 2005. Sampul Mata Pelajaran Seni Teater 1. Lamongan: Alam Pustaka.

Purwadi, 2007. Ensiklopedi Adat Istiadat Budaya Jawa, Yogyakarta: SHAIDA.

Rahimsyah, 2009. Kumpulan Legenda Nusantara.Surabaya:Amelia. 